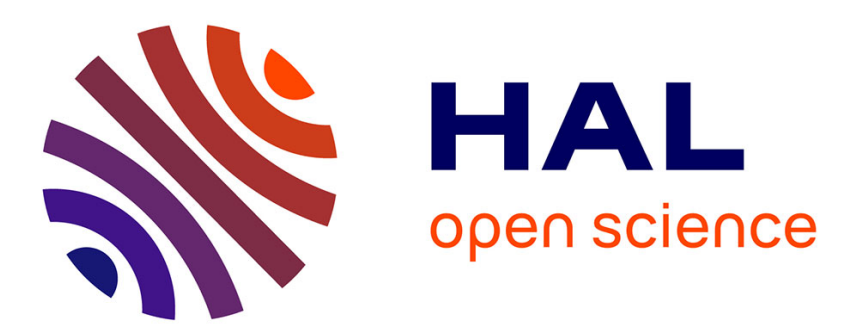

\title{
Kinetics of species produced by an electron-beam controlled discharge in oxygen at atmospheric pressure
}

\author{
J. Bonnet, G. Fournier, D. Pigache, M. Lecuiller
}

\section{To cite this version:}

J. Bonnet, G. Fournier, D. Pigache, M. Lecuiller. Kinetics of species produced by an electron-beam controlled discharge in oxygen at atmospheric pressure. Journal de Physique Lettres, 1980, 41 (20), pp.477-478. 10.1051/jphyslet:019800041020047700 . jpa-00231825

\section{HAL Id: jpa-00231825 https://hal.science/jpa-00231825}

Submitted on 1 Jan 1980

HAL is a multi-disciplinary open access archive for the deposit and dissemination of scientific research documents, whether they are published or not. The documents may come from teaching and research institutions in France or abroad, or from public or private research centers.
L'archive ouverte pluridisciplinaire HAL, est destinée au dépôt et à la diffusion de documents scientifiques de niveau recherche, publiés ou non, émanant des établissements d'enseignement et de recherche français ou étrangers, des laboratoires publics ou privés. 


\title{
Kinetics of species produced by an electron-beam controlled discharge in oxygen at atmospheric pressure (*)
}

\author{
J. Bonnet, G. Fournier, D. Pigache and M. Lécuiller (**) \\ Office National d'Etudes et de Recherches Aérospatiales, 92320 Châtillon. France \\ $\left({ }^{* *}\right)$ Laboratoire de Physique des Décharges (†), Ecole Supérieure d'Electricité, Gif-sur-Yvette, France
}

(Reçu le 29 avril 1980, accepté le 28 août 1980)

\begin{abstract}
Résumé. - L'évolution dans le temps des espèces chargées, des métastables et de l'ozone est obtenue à l'aide d'un programme de calcul. Certains résultats sont comparés à des expériences antérieures.
\end{abstract}

Abstract. - Time evolution of charged species, metastable species and ozone is obtained from a computer code. Some results can be compared with previous experiments.

The progress of gas lasers and chemical synthesis reactors using electron-beam controlled discharge requires sophisticated modelling for interpreting experiments and planning subsequent technical developments. This modelling is based on three computer codes permitting the calculation of :

- electron-beam energy branching towards the various excitation, dissociation and ionization processes ;

- discharge energy branching for the same processes ;

- time evolution of involved species densities.

The results presented in this letter have been obtained by means of the last code using data provided by the first two. The species density $N_{i}$ depends upon the different species considered $N_{j}$ and the reaction constants $A_{m}$ (reactions of two bodies $j_{1}$ and $j_{2}$ ) and $A_{n}$ (reactions of three bodies $j_{1}, j_{2}$ and $j_{3}$ ). The evolution of densities $N_{i}$ is given by the equations system :

$$
\begin{aligned}
\frac{\mathrm{d} N_{i}}{\mathrm{~d} t}=\sum_{m} A_{m} N_{j_{1}} N_{j_{2}}+\sum_{n} A_{n} N_{j_{1}} & N_{j_{2}} N_{j_{3}}+ \\
& +v\left(N_{i}^{\prime}-N_{i}\right) .
\end{aligned}
$$

The last term of equations (1) takes into account the effect of the gas flow. $v$ is the renewal rate. It is assumed that the density $N_{i}$ is uniform in the discharge chamber and that the incoming gas with

(*) This research has been supported by D.R.E.T.

(†) E.R. 114 du C.N.R.S. densities $N_{i}^{\prime}$ is immediately mixed in the whole discharge volume. The interest of the code is its efficiency : a computation time of the order of $1 \mathrm{~min}$. is enough to follow density variations of several tens of decades with time constants difference of more than ten decades. These performances are achieved by temporarily setting at equilibrium, that is $\mathrm{d} N_{i} / \mathrm{d} t=0$ in equation (1), the species having the

Table I. - Selected reactions list. Several figures numbers do not imply an especially accurate value of

\begin{tabular}{|c|c|c|c|}
\hline No & Reaction & Rate & efs. \\
\hline- & & . & - \\
\hline 1 & $+\mathrm{O}_{2} \rightarrow \mathrm{e}+$ ions + & $1.805 \mathrm{~s}^{-1}$ & [5] \\
\hline 2 & $\mathrm{e}+2 \mathrm{O}_{2} \rightarrow \mathrm{O}_{2}+$ ions - & $1.250 \times 10^{-31} \mathrm{~cm}^{6} / \mathrm{s}$ & {$[2$} \\
\hline 3 & $\mathrm{e}+\mathrm{O}_{2} \rightarrow \mathrm{O}+$ ions - & $2.109 \times 10^{-11} \mathrm{~cm}^{3} / \mathrm{s}$ & [2] \\
\hline 4 & $\mathrm{e}+\mathrm{O}_{2} \rightarrow \mathrm{e}+\mathrm{O}_{2}^{1} \Delta$ & $4.848 \times 10^{-10} \mathrm{~cm}^{3} / \mathrm{s}$ & [2] \\
\hline 5 & $\mathrm{e}+\mathrm{O}_{2} \rightarrow \mathrm{e}+\mathrm{O}_{2}{ }^{1} \Sigma$ & $1.146 \times 10^{-10} \mathrm{~cm}^{3} / \mathrm{s}$ & [2] \\
\hline 6 & $\mathrm{e}+\mathrm{O}_{2} \rightarrow \mathrm{e}+2 \mathrm{O}$ & $2.274 \times 10^{-10} \mathrm{~cm}^{3} / \mathrm{s}$ & [2] \\
\hline 7 & $\mathrm{e}+\mathrm{O}_{2} \rightarrow \mathrm{e}+\mathrm{O}+\mathrm{O}^{*}$ & $5.936 \times 10$ & [2] \\
\hline 8 & ns -+ ions $+\rightarrow 2$ & $2.000 \times 10^{-}$ & [6] \\
\hline 9 & $\mathrm{O}+\mathrm{O}_{2}{ }^{1} \Delta \rightarrow \mathrm{O}+\mathrm{O}_{2}$ & $1.300 \times 10^{-16} \mathrm{~cm}^{3} / \mathrm{s}$ & [7] \\
\hline 0 & $\mathrm{O}+\mathrm{O}_{2}{ }^{-1} \Sigma \rightarrow \mathrm{O}+\mathrm{O}_{2}$ & $3.000 \times 10^{-12} \mathrm{~cm}^{3} / \mathrm{s}$ & {$[7]$} \\
\hline 1 & $\mathrm{O}_{2}+\mathrm{O}_{2}{ }^{1} \Delta \rightarrow 2 \mathrm{O}_{2}$ & $2.200 \times 10^{-18} \mathrm{~cm}^{3} / \mathrm{s}$ & [8] \\
\hline 2 & $\mathrm{O}_{2}+\mathrm{O}_{2}{ }^{1} \Sigma \rightarrow 2 \mathrm{O}_{2}$ & $4.000 \times 10^{-17} \mathrm{~cm}^{3} / \mathrm{s}$ & [9] \\
\hline 3 & $\mathrm{O}_{3}+\mathrm{O}_{2}^{1} \Delta \rightarrow \mathrm{O}+2 \mathrm{O}_{2}$ & $3.672 \times 10^{-15} \mathrm{~cm}^{3} / \mathrm{s}$ & [10] \\
\hline 4 & $\mathrm{O}_{3}+\mathrm{O}_{2}{ }^{1} \Sigma \rightarrow \mathrm{O}+2 \mathrm{O}_{2}$ & $1.000 \times 10^{-11} \mathrm{~cm}^{3} / \mathrm{s}$ & [11] \\
\hline 5 & $2 \mathrm{O}_{2}^{1} \Delta \rightarrow \mathrm{O}_{2}+\mathrm{O}_{2}^{1} \Sigma$ & $2.000 \times 10^{-17} \mathrm{~cm}^{3} / \mathrm{s}$ & [12] \\
\hline 6 & $\mathrm{O}+\mathrm{O}_{3} \rightarrow 2 \mathrm{O}_{2}$ & $3.786 \times 10^{-15} \mathrm{~cm}$ & [13] \\
\hline 7 & $\mathrm{O}+2 \mathrm{O}_{2} \rightarrow \mathrm{O}$ & $3.653 \times 10^{-34} \mathrm{~cm}^{6} / \mathrm{s}$ & [13] \\
\hline 18 & $2 \mathrm{O}+\mathrm{O}_{2} \rightarrow 2 \mathrm{O}$ & $3.000 \times 10^{-}$ & [14] \\
\hline 19 & $\mathrm{O}_{2}+\mathrm{O}_{3} \rightarrow \mathrm{O}+2$ & $9.540 \times 10^{-27} \mathrm{~cm}^{3} / \mathrm{s}$ & [13] \\
\hline 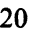 & $\mathrm{O}^{*}+\mathrm{O}_{2} \rightarrow \mathrm{O}+\mathrm{O}_{2}{ }^{1} \Sigma$ & $4.000 \times 10^{-11} \mathrm{~cm}^{3} / \mathrm{s}$ & [15] \\
\hline
\end{tabular}
the physical constant. 
fastest evolution speeds. The algorithm validity has been tested by a classical resolution with thin steps.

The species considered in an electron-beam controlled discharge in pure oxygen at atmospheric pressure are molecular oxygen in the fundamental state $\left(\mathrm{O}_{2}\right)$, the a ${ }^{1} \Delta_{\mathrm{g}}$ state $\left(\mathrm{O}_{2}{ }^{1} \Delta\right)$ and the $\mathrm{b}^{1} \Sigma_{\mathrm{g}}^{+}$ state $\left(\mathrm{O}_{2}{ }^{1} \Sigma\right)$, atomic oxygen in the fundamental state $(\mathrm{O})$ and the ${ }^{1} \mathrm{D}$ state $\left(\mathrm{O}^{*}\right)$, ozone $\left(\mathrm{O}_{3}\right)$, positive ions (ions + ), negative ions (ions-) without more detailed identification and electrons (e). The retained reactions are numbered and identified in table $I$. Although beam effects [1] and discharge effects [2] can be coupled more correctly, ionization is the only beam effect which has to be considered for the parameters chosen in this letter.

The experimental conditions. [3] corresponding to this calculation are given in table II. Some reaction rates in table I depend on various discharge and beam properties given in table II. It should be noted that thermal dissociation of ozone (reaction 19) is quite negligible at room temperature. The variations of species densities are shown in figure 1 for the third pulse which already corresponds to the periodic regime in these conditions. With drift velocities of $218 \mathrm{~m} / \mathrm{s}$ for the ions [4] and $8.2 \times 10^{4} \mathrm{~m} / \mathrm{s}$ for the electrons [2], the calculated current at pulse maximum is $0.13 \mathrm{~A} / \mathrm{cm}^{2}$ to be compared with the measured value $0.12 \mathrm{~A} / \mathrm{cm}^{2}$. The average ozone concentration deduced from figure 1 is $4.8 \times 10^{-4}$ to be compared with the measured value $3.8 \times 10^{-4}$. As some hypothesis can be discussed, in particular the choice of the dissociation reactions and their constants $[2,3]$, this agreement is partly fortuitous.

The numerical results will help defining the next experiments of ozone production whose purpose is to demonstrate the possibility of ozone production in conditions of economical interest. The model is also being used for rare gas-oxygen-iodine mixtures
Table II. - Calculations parameters.
Pressure

Temperature

Renewal rate

Beam voltage

Measured beam current

Beam pulse full width at half maximum

Repetition rate

Electrodes gap

Discharge voltage

Electric field/gas density

Discharge current density

Average ozone concentration
$1.15 \mathrm{bar}$

$300 \mathrm{~K}$

$1.5 \mathrm{~s}^{-1}$

$100 \mathrm{kV}$

$8 \mathrm{~mA} / \mathrm{cm}^{2}$

$24 \mu \mathrm{s}$

$0.8 \mathrm{~Hz}$

$2 \mathrm{~cm}$

$20.1 \mathrm{kV}$

$3.6 \times 10^{-16} \mathrm{~V} \mathrm{~cm}^{2}$

$0.12 \mathrm{~A} / \mathrm{cm}^{2}$

$3.8 \times 10^{-4}$

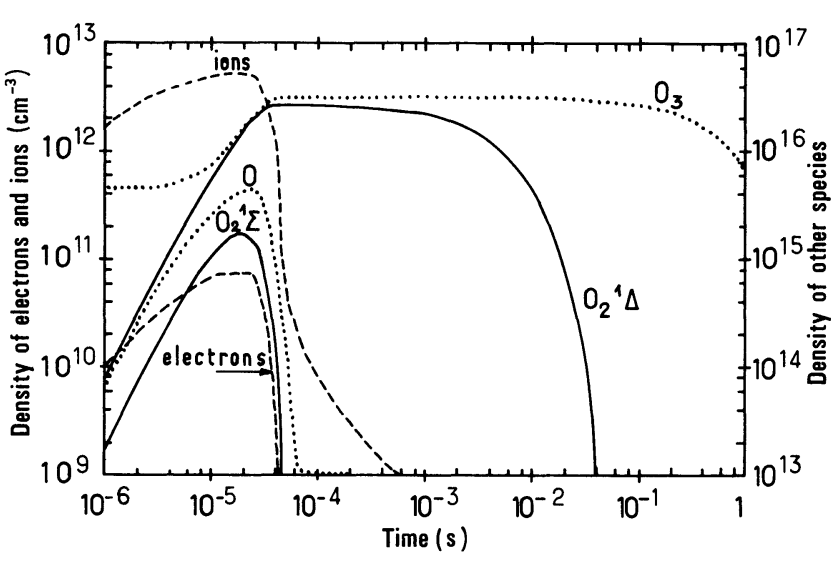

Fig. 1. - Time evolution of species density.

in view of finding the working conditions of a potential laser based on excitation transfer from $\mathrm{O}_{2}\left({ }^{1} \Delta\right)$ to atomic iodine.

\section{References}

[1] Fournier, G., Bonnet, J., Bridet, J., Fort, J. and PigaCHE, D., J. Physique Colloq. 40 (1979) C7-777-778.

[2] Fournier, G., Bonnet, J. and Pigache, D., J. Physique Lett. 41 (1980) L-173.

[3] Fournier, G., Bonnet, J., Fort, J., Pigache, D. and LécuilLER, M., 4th IUPAC Conf. on Plasma Chemistry, Zürich, August 27th-September 1st, 1979.

[4] Snuggs, R. M., Volz, D. J., Schummers, J. M., Martin, D. W. and MCDaniel, E. W., Phys. Rev. A 3 (1971) 477-487.

[5] Fournier, G., Bonnet, J., Bridet, J., Fort, J. and PigaCHE, D., Bull. Am. Phys. Soc. 25 (1980) 110.

[6] McGowan, S., Can. J. Phys. 45 (1967) 439-448.

[7] Dumas, J. L., Les propriétés de l'oxygène singulet, Ecole d'Eté sur les " Réactions atomiques et moléculaires dans les plasmas », Les Houches, August 17-28, 1976.
[8] Hampson, R. F., Braun, W., Brown, R., Garvin, D., Herron, J. T., JUIE, R. E., Kurylo, M. J., Laufor, A. J., MCKInley, J. D., OKaKe, H., ScheER, M. D. and Tsang, W., J. Phys. Chem. Ref. Data 2 (1973) 267.

[9] Lawton, S. A., Novick, S. E., Broida, H. P. and Phelps, A. V., J. Chem. Phys. 66 (1977) 1381-1382.

[10] Findlay, F. D. and Snelling, D. R., J. Chem. Phys. 54 (1971) 2750-2755.

[11] Snelling, D. R., Can. J. Chem. 52 (1974) 257.

[12] Derwent, R. G. and Thrush, B. A., Trans. Faraday Soc. 67 (1971) 2036-2043.

[13] Michael, J. V., J. Chem. Phys. 54 (1971) 4455-4459.

[14] Niles, F. E., J. Chem. Phys. 52 (1970) 408-424.

[15] Streit, G. E., Howard, C. J., Schmeltekopf, A. L., Davidson, J. A. and Schiff, H. I., J. Chem. Phys. 65 (1976) 4761-4764. 